\title{
Twice-Exceptional Gifted Students: Needs, Challenges, and Questions to Ponder
}

\author{
Khlood K. Alshareef \\ University of Arkansas \\ kkalshar@email.uark.edu
}

\begin{abstract}
Gifted students are usually known as students who have exceptional cognitive and learning abilities. This can be made clear through their learning performance or test scores. However, there are other students who have been identified as gifted and talented, yet have some learning and /or physical disabilities, and these are called twice-exceptional students. Identifying this population of gifted students is usually problematic because their disabilities and difficulties may mask their abilities and vice versa. It has been suggested that twice-exceptional students' skills and abilities cannot be improved simply by working harder. Instead, these students need teachers to understand their strengths and weaknesses, use teaching strategies that fit their disabilities and serve their needs, and include their parents and educators in their learning process. Thus, this conceptual paper provides an extensive overview of the needs, challenges, and teaching strategies related to twice-exceptional students.
\end{abstract}

Keywords: gifted and talented students; twice-exceptional students; gifted education; special education 
TWICE-EXCEPTIONAL STUDENTS

\section{Introduction}

Numerous studies indicate that students have different abilities and capacities for learning. Some students have high thinking abilities and exceptional capabilities that enable them to achieve significantly higher than the average student (Davis \& Rimm, 2011; Gagné, 2003; Hébert, 2010; Sternberg \& Davidson, 2005). Those students are described as gifted and talented students. Worrell, Subotnik, Olszewski-Kubilius, and Dixson (2019) defined gifted and talented students as: "those who are exhibiting superior performance in a particular domain relative to peers" (p. 552). However, some students have been identified as gifted and talented, yet have some learning and/or physical disabilities, and these are called twice-exceptional students.

\section{Twice-Exceptional Students}

According to Kaufman (2018), twice exceptional are students who have been identified as gifted and talented in one or more areas of exceptionality and have elusive learning disabilities. Similarly, Baldwin, Baum, Pereles, and Hughes (2015) define twice-exceptional students as:

Twice exceptional individuals evidence exceptional ability and disability, which results in a unique set of circumstances. Their exceptional ability may dominate, hiding their disability; their disability may dominate, hiding their exceptional ability; each may mask the other so that neither is recognized or addressed. (p. 212).

\section{Types of Twice-Exceptionality}

There are many groups of twice-exceptional students that distinguish them from other students (Baldwin, Omdal, \& Pereles, 2015). The first group of twice-exceptional students is gifted students with physical disabilities. Gallagher (2006) indicates that in the majority of cases, physical disability and cognitive ability are unrelated. Thus, students with an extreme physical disability may be classified as gifted, but they need appropriate and special education services. 
TWICE-EXCEPTIONAL STUDENTS

Gallagher (2006) adds that Stephen Hawking, a physicist who won a Nobel Prize, is one of the examples of a gifted person with a physical disability. The second group according to Gallagher (2006), consists of gifted students who have sensory disabilities. Students with sensory disabilities such as deafness, blindness, or smell, touch, or taste impairment can be identified as gifted students and attend regular schools, but they require provisions that accommodate both their giftedness and their disability (Gallagher 2006). Gallagher continues to say that Helen Keller, who was deaf and blind, is a great example of a person who had sensory disabilities and was gifted.

Moreover, the third type of twice-exceptional students is gifted students with emotional and/or behavioral disorders. According to Hébert (2010), gifted and talented students might experience emotional or psychosocial difficulties. However, in many cases, the giftedness of these students might be unrecognized, and the attention goes only on their disruptive behaviors. Gallagher (2006) mentions that the mathematician John Nash Jr., a Nobel prize-winner who struggled with schizophrenia is an example of a gifted individual who has an emotional disorder. The fourth group is gifted students with Attention-Deficit/Hyperactivity Disorder (ADHD) (King, 2005). ADHD, according to Hébert (2010), is a condition of the brain that impacts an individual's ability to pay attention. ADHD includes a combination of problems, such as difficulty in sustaining attention, hyperactivity, and impetuous behaviors. Hébert (2010) continues to say that gifted students with ADHD have difficulty focusing their attention, completing their work, following directions, and organizing their school materials. At the same time, they show an advanced ability and a high level of performance.

In addition, Gallagher (2006) states that gifted students with Asperger's Syndrome are the fifth group of twice-exceptional students. Neihart (2000) believes that these groups of 
TWICE-EXCEPTIONAL STUDENTS

students share many similar syndromes and characteristics of autistic individuals, but they do not meet the formal diagnostic criteria for autism. Neihart (2000) also notes that students with Asperger's Syndrome usually show a great passion for increasing their knowledge and excel in a variety of areas. The final type of twice-exceptional is gifted students with learning disabilities (Gallagher, 2006; Hébert, 2010). Gallagher (2006) states that "many students with this type of profile might not be identified as gifted because their areas of strength and weakness move them toward average performance and they might appear to be in need of neither gifted nor special education services" (p.6).

\section{Identification of Twice-Exceptional Children}

Much research has been done to understand the importance of identifying gifted and talented students. Some researchers have focused on the identification procedures, while others studied the issues involved in the identification process (Davis \& Rimm, 2011; Gagné, 2003; Gallagher, 2006; Hebert, 2010; Kay, 2000; McCoach, Kehle, Bray, \& Siegle, 2001; Trail, 2012). Gallagher (2006) states that there is a consensus among many researchers that there are many identification factors that help in identifying students with exceptional and above-average abilities. Some of these factors are students' performance in different standardized and informal assessments by teachers, behavioral indicators, teachers' or parents' nominations, peers' reports, students' self-reports, intelligence tests, creativity tests and multiple intelligence assessments (Karnes, Shaunessy \& Bisland, 2004; McCoach, Kehle, Bray, \& Siegle, 2001). These factors can determine whether a student is gifted and needs special learning practices.

However, according to King (2005) identifying gifted twice-exceptional students can be difficult since their gifts might be unnoticed and the main attention goes to their disabilities. In other words, teachers might unintentionally focus on students' disabilities and ignore their gifts. 
TWICE-EXCEPTIONAL STUDENTS

Moreover, King (2005) adds that for this reason, identifying twice-exceptional students is more of a challenge than identifying gifted and talented students.

In addition, Kay (2000) indicates that the most important step in identifying twiceexceptional students is understanding and knowing their characteristics. These characteristics can help teachers identify students who are gifted and identify their learning or physical disabilities. King (2005) states that another way to identify twice-exceptional students is to keep journal notes and records of how a student performs in class. Teachers in these notes should look for hidden talents in verbal expression, creativity, and critical thinking skills. These skills can be indicators of students with exceptional abilities. The notes also should include students' physical, learning, or sensory difficulties which can be observed by teachers during classroom instruction (King, 2005).

Furthermore, Bradley, Danielson, and Doolittle (2005) believe that the Response to Intervention (RTI) model can be very helpful in identifying a twice-exceptional student. Bradley, Danielson, and Doolittle (2005) state that "RTI has been broadly described as a process in which students are provided quality instruction, their progress is monitored, those who do not respond appropriately are provided additional instruction and their progress is monitored, and those who continue to not respond appropriately are considered for special education services" (p. 486). Moreover, RTI model provides teachers with a framework to assess students' abilities and helps in making the identifying decisions based on structured, data-based problem solving, and flexible service delivery.

Karnes, Shaunessym, and Bisland (2004) indicate that another identification strategy is forming a multidisciplinary team responsible for referrals and further evaluation of twiceexceptional students. This team should include teachers, school counselors, and gifted and 
TWICE-EXCEPTIONAL STUDENTS

talented specialists. The team shall meet and discuss students' progress and performance to determine which have exceptional abilities and learning or physical disabilities. McCoach, Kehle, Bray, and Siegle (2001) note that identifying twice-exceptional will be problematic because disabilities may mask abilities and vice versa. They add that the identification process should not be limited to test scores because these assessments often preclude twice-exceptional students from participation in gifted programs because they may not meet the required score.

\section{Characteristics of Twice-Exceptional Students}

Although the characteristics of students who are identified as gifted with a learning disability differ from student to student, there are general characteristics found in many studies. In addition, some of the characteristics may not appear in every twice-exceptional student. However, these characteristics can be stronger in some students than in others (Gallagher, 2006; Hebert, 2010; Kay, 2000; McCoach, Kehle, Bray, \& Siegle, 2001; Trail, 2012).

First, twice-exceptional students struggle with basic skills because of cognitive processing difficulties (Baldwin, Omdal, \& Pereles, 2015). These children are expected to acquire specific academic skills. However, many basic skills require abilities that these students do not possess because of their learning disabilities. For instance, Baldwin, Omdal, and Pereles, (2015) state that these students might experience reading problems.

Second, twice-exceptional students show high verbal ability but they might face extreme difficulty in written language (King, 2005). King indicates that despite the high verbal ability of twice-exceptional students, they may use language in inappropriate ways and at inappropriate times. That is, they might struggle in using the correct language in the correct situations. In addition, these students may have strong questioning attitudes. Another characteristic is these 
TWICE-EXCEPTIONAL STUDENTS

students often have an excellent ability in solving problems (Trail, 2011). They show an outstanding ability in solving problems that require critical thinking and decision making skills.

Moreover, twice-exceptional students sometimes display unusual imagination that helps them in creating original, unusual ideas that require extremely divergent and complicated minds (Trail, 2011). Another characteristic of twice-exceptional students is that usually they demonstrate strong observation skills but have difficulty with memory skills (Winebrenner, 2003). These observation skills, according to Winebrenner (2003), allow many students to demonstrate special talents in visuals events or art.

Finally, twice-exceptional students might appear immature many times despite their age and high cognitive ability due to the fact that they may use anger or crying to express feelings and deal with difficulties (King, 2005). Significantly, according to Besnoy (2006), understanding these characteristics and traits will help teachers, parents, and educators deal with their various social and emotional needs.

\section{Addressing the Social and Emotional Needs of Twice-Exceptional Students}

King (2005) indicates that twice-exceptional students are "often caught between two worlds" (p.6). That is, most of these students have high self-confidence about their abilities and strong internal motivations to succeed, yet they might fail in certain areas due to their disabilities. Some of these students have the belief that their bodies, brains, or senses do not do what they want them to do (King, 2005). In other words, twice-exceptional students have strong beliefs and confidence about their abilities and that causes them to raise their expectations of what they will be able to achieve (Kay, 2000).

According to Trail (2006), gifted students with physical or learning disabilities might experience failure more than they expect, and this will lead them to fear failure in the future. As 
TWICE-EXCEPTIONAL STUDENTS

a result, some of these students might be rushing through or avoid doing many tasks in which they fear failure (Trail, 2006). This also makes these students confused about whether the cause of their failure is their talents or disabilities (King, 2005). Moreover, failure in completing tasks or achieving their goals leads twice-exceptional students to experience many emotional difficulties such as frustration, disappointment, anxiety, fear of failure, low self-esteem, and anger (Trail, 2006). To illustrate, King (2005) mentions that the source of twice-exceptional' anger is that they usually have high expectations and challenge themselves by working harder than other students, yet they might be not satisfied with the results of their work. These students might blame their disabilities for not successfully getting the desirable results, and that causes them to be angry and disappointed.

Furthermore, King (2005) believes that low self-esteem can be caused by failing to deal with difficult tasks and control their frustration. Difficult tasks that tap into their academic weakness cause many twice-exceptional students to lower their self-esteem and lose their selfconfidence. King (2005) also states that twice-exceptional students might not only have fear of failure but also fear of success. In other words, after successfully completing a task, they might experience only a short-lived elation due to their anxiety of succeeding in the next tasks. King (2005) continues to say that failing to replicate the level of success in the next assignment will put these students under pressure which will cause them to fear success. Consequently, what can be done to help these students?

According to Trail (2011), twice-exceptional students need support form teachers, parents, and their peers to overcome these emotional difficulties which may affect their academic achievement. Many strategies can be implemented to support the social and emotional needs of this population of students. To begin with, during the classroom instructions, teachers have to 
TWICE-EXCEPTIONAL STUDENTS

increase students' understanding of their abilities' strengths and weaknesses (Kay, 2000). By

understanding their abilities, students will be better prepared to deal with the emotional difficulties they might encounter when dealing with difficult tasks. Moreover, King (2005)

suggests that students have to be taught some coping strategies that they can use when becoming angry, frustrated or disappointed. King (2005) adds that these strategies will increase students' commitment and persistence to deal with challenging tasks and to achieve their short-term goals.

In addition, Winebrenner (2003) recommends that teachers should encourage twiceexceptional students to set realistic short-term and long-term goals, accept their failure, and reward their success. These also can be true for students' parents who should maintain their expectations within their children's abilities and not ask them for more than what they can do. Finally, Trail (2006) emphasizes the importance of increasing the awareness of parents about their children's abilities, challenges, and unique needs. Parents, according to Trail, play a major and important role in addressing and dealing with twice-exceptional children. In short, understanding twice-exceptional students' emotional and social needs should be the aim of all teachers, and as King (2005) mentions:

Teachers must aim to strengthen these students' academic abilities and nurture their gifts while also supporting the social and emotional struggles that twice-exceptional students face inside and outside the classroom. By providing support that targets the whole child, we have the opportunity to tap the full potential of gifted students with learning disabilities. (p. 20)

\section{Effective Teaching Strategies with Twice-Exceptional Students}

Teaching students who are twice-exceptional can be very challenging (Besnoy, 2006). According to Winebrenner (2003), the main issue with teaching these students is that their gifts will be unnoticed in favor of their learning and physical difficulties. Lee and Ritchotte (2018) also mention that "educating twice-exceptional students requires school personnel to be trained 
TWICE-EXCEPTIONAL STUDENTS

in recognizing the characteristics of these unique learners" (p. 69). Winebrenner (2003) indicates several strategies that help to address and to deal with the different learning needs of students who have been identified as twice-exceptional.

First, teachers have to teach students to appreciate individual differences (Winebrenner, 2003). It is important for students to appreciate, respect, and support the individual differences among them. These differences might range from obvious physical differences to observable differences in learning abilities. This also will help create a positive atmosphere where twiceexceptional students can be motivated and engaged despite their learning or physical disabilities (Winebrenner, 2003).

Second, Trail (2011) suggests that teachers have to use a wide variety of teaching strategies to match the needs of all students. In other words, teachers have to understand that many twice-exceptional students might be global learners who prefer visual and tactilekinesthetic kinds of learning (Trail, 2011). Other students with sensory challenges might desire quiet places, appreciate multiple opportunities for movement, and prefer relaxed postures. Providing students with their preferable kinds of learning will enhance the classroom environment and ensure more effective and productive learning (Trail, 2011).

Third, Besnoy, (2006) suggests that it is important for teachers to teach content by teaching concepts first and details second. This will help students see the big picture before diving into the details. For example, Besnoy (2006) indicates that students can watch a video before and after studying a new unit of work, hear a story read aloud before reading it individually, and work with graphic organizers before being introduced to the lessons.

Fourth, teachers have to teach students how to set realistic short-term goals and to take credit for reaching those goals (Winebrenner, 2003). This strategy, according to Winebrenner, is 
TWICE-EXCEPTIONAL STUDENTS

highly effective in helping discouraged learners become motivated to reach their goals. Setting short-term goals will help increase the sense of mastery and accomplishment among students, especially students with learning difficulties.

Fifth, another strategy that can be effectively used with twice-exceptional students is tying past learning to new content (King, 2005). One characteristic of twice-exceptional students is that they have difficulty with memory skills. According to King (2005), connecting past experiences and knowledge to the new content is important for twice-exceptional students in order to learn and generalize new concepts. Hence, connecting what they have already learned to the new content will help them improve their memory skills and ensure learning both the past and the new content.

Finally, providing students with activities that immerse all the learning senses is an important strategy for students with physical or sensory disabilities (Winebrenner, 2003). For instance, teachers can use visuals to see the patterns and connections between things, integrate musical chants, rhymes, or rhythms for students who respond to those methods, and utilize team games where students can walk to different areas (Winebrenner, 2003). Also, with Tbilingual gifted and twice exceptional students, it is important for teachers to use authentic materials that promote and facilitate learning experiences. (Albiladi, 2019)These are some of the strategies and techniques that can be used in a classroom which include some twice-exceptional students. Winebrenner (2003) states that twice-exceptional students' skills and abilities cannot be improved simply by working hard or increasing their learning efforts. Their learning challenges require teachers to use the teaching strategies that fit their disabilities and serve their needs. 
TWICE-EXCEPTIONAL STUDENTS

\section{References}

Albiladi, W. S. (2019). Exploring the Use of Written Authentic Materials in ESL Reading Classes: Benefits and Challenges. English Language Teaching, 12(1), 67-77.

Baldwin, L., Baum, S., Pereles, D., \& Hughes, C. (2015). Twice-exceptional learners: The journey toward a shared vision. Gifted Child Today, 38(4), 206-214.

Baldwin, L., Omdal, S. N., \& Pereles, D. (2015). Beyond stereotypes: Understanding, recognizing, and working with twice-exceptional learners. Teaching Exceptional Children, 47(4), 216-225.

Besnoy, K. D. (2006). Successful strategies for twice-exceptional students. Waco, TX: Prufrock Press Inc.

Bradley, R., Danielson, L., \& Doolittle, J. (2005). Response to intervention. Journal of Learning Disabilities, 38(6), 485-486.

Chin-Wen Lee \& Jennifer A. Ritchotte (2018). Seeing and Supporting Twice Exceptional Learners, The Educational Forum, 82(1), 68-84, DOI: 10.1080/00131725.2018.1379580

Davis, G. A., \& Rimm, S. B. (2011). Education of the gifted and talented. Boston, MA: PrenticeHall, Inc.

Gagné, F. (2003). Transforming gifts into talents. In N. Colangelo \& G.A. Davis (Eds.), Handbook of gifted education (pp. 60-74). Boston, MA: Allyn \& Bacon.

Gallagher, J (2006). The Twice-Exceptional Dilemma. Washington, DC: National Education Association.

Hébert, T. P. (2010). Understanding the social and emotional lives of gifted students. Boston, MA: Sourcebooks.

Karnes, F. A., Shaunessy, A., \& Bisland, A. (2004). Gifted students with disabilities are we finding them? Gifted Child Today, 27(4), 16-22

Kaufman, S. B. (Ed.). (2018). Twice Exceptional: Supporting and Educating Bright and Creative Students with Learning Difficulties. Oxford, UK: Oxford University Press.

Kay, K. (2000). Uniquely Gifted: Identifying and Meeting the Needs of Twice-Exceptional Students. Gilsum, NH: Avocus Publishing Inc.

King, E. W. (2005). Addressing the social and emotional needs of twice exceptional students. Teaching Exceptional Children, 38(1), 16-20

Lee, C. W., \& Ritchotte, J. A. (2018). Seeing and supporting twice-exceptional learners. The Educational Forum, 82(1), 68-84. 
McCoach, B. D., Kehle, T. J., Bray, M. A., \& Siegle, D. (2001). Best practices in the identification of gifted students with learning disabilities. Psychology in the Schools 38, (5), 403-411.

Neihart, M. (2000). Gifted children with Asperger's syndrome. Gifted child quarterly, 44(4), 222-230.

Sternberg, R. J., \& Davidson, J. E (2005). Conceptions of giftedness. London, UK: Cambridge University Press.

Trail, B. (2006). Parenting twice-exceptional children through frustration to success. Parenting for High Potential, 1(3), 26-30.

Trail, B. (2011). Twice-exceptional gifted children: Understanding, teaching, and counseling gifted students. Naperville, IL: Sourcebooks, Inc.

Winebrenner, S. (2003). Teaching strategies for twice-exceptional students. Intervention in School and Clinic, 38(3), 131-137.

Worrell, F. C., Subotnik, R. F., Olszewski-Kubilius, P., \& Dixson, D. D. (2019). Gifted students. Annual review of psychology, 70(1), 551-576. 